\title{
Wpływ ćwiczeń mięśni dna miednicy z udziałem i bez udziału mięśni synergistycznych na jakość życia kobiet z wysiłkowym nietrzymaniem moczu*
}

\author{
The impact of pelvic floor muscle exercises with and without synergistic muscles \\ on the quality of life of women with stress urinary incontinence
}

\author{
Magdalena Ptak $\bowtie$ \\ Pomorski Uniwersytet Medyczny w Szczecinie, Samodzielna Pracownia Rehabilitacji Medycznej, ul. Żołnierska 54, 71-210 Szczecin
}

$\triangle$ ptak.magda@gmail.com

\begin{abstract}
Introduction: Stress urinary incontinence (SUI) is an ailment diagnosed in many women in different periods of life. It is estimated that nearly $60 \%$ of them will experience the effect of SUI on the quality of life (QOL) in the perimenopausal period. The International Continence Society (ICS) recommended pelvic floor muscle (PFM) exercise as first line treatment.

The aim of this study was to compare the QOL of patients with stage 1 SUI that performed PFM and the synergistic muscle (PFM and SM) exercise and isolated PMF (PFM) exercise for the period of 3 months. The additional objective was to evaluate the influence of menopausal status, body mass index (BMI), waist-hip ratio (WHR) and the number of births given on the effectiveness of treatment.

Materials and methods: After urodynamic testing executed at the Clinic of Gynaecology, Endocrinology and Gynaecologic Oncology in the Pomeranian Medical University in Szczecin (in Poland), 140 patients were selected. Women were in the perimenopausal period and suffered from SUI stage 1 . The conservative treatment was carried out under supervision in 2 groups, 70 patients
\end{abstract}

\section{ABSTRAKT}

Wstęp: Wysiłkowe nietrzymanie moczu (WNM) jest dolegliwością dotyczącą wielu kobiet w różnych okresach życia. Szacuje się, iż prawie $60 \% \mathrm{z}$ nich $\mathrm{w}$ wieku perimenopauzalnym doświadczy wpływu WNM na jakość życia (QOL). Według International Continence Society leczenie rozpoczyna się od metod zachowawczych, do których zalicza się gimnastykę mięśni dna miednicy (MDM). Celem pracy było porównanie QOL pacjentek z WNM I stopnia po zastosowaniu gimnastyki MDM z mięśniem synergistycznym oraz gimnastyki wyłącznie MDM, którą przeprowadzono w okresie 3 miesięcy. Dodatkowo oceniono wpływ wskaźnika masy ciała (BMI), wskaźnika dystrybucji tkanki tłuszczowej w organizmie (WHR), liczby porodów oraz statusu menopauzalnego na efektywność leczenia.

Materiały i metody: Do badania zakwalifikowano 140 kobiet będących w okresie okołomenopauzalnym, ze zdiagnozowanym WNM I stopnia. W obu grupach wiek pacjentek wynosił średnio 51-53 lata, a BMI wahało się w granicach $27,4 \mathrm{~kg} / \mathrm{m}^{2}$, natomiast WHR wynosił 0,88 i 0,81. Zastosowano kwestionariusz each. The mean age of women was $51-53$ years, BMI $-27.4 \mathrm{~kg} / \mathrm{m}^{2}$ and WHR was 0.88 (first group) and 0.81 (second group). Before and after the treatment, patients' QOL was evaluated with the use of the ICIQ LUTS qol questionnaire. Moreover, the patients in both groups received vaginal oestriol. Statistica v. 12.0 PL, StatSoft, USA, was used for statistical calculations.

Results: Analysis demonstrated the effectiveness of both exercise protocols. The study revealed that exercise according to protocol $\mathrm{A}$ (PMF and SM) is more effective than protocol B (PMF). There was no change in QOL in personal relationships. The influence of menopausal status, WHR and number of births was proven. Conclusions: PFM and SM exercise and PFM exercise alone improved the QOL of women with SUI stage 1. However, a stronger impact was observed in the physiotherapy of PFM and SM. The PFM and SM exercise was proven to be more effective than the PFM exercise alone when performed by women with SUI in their premenopausal period, with a gynoidal body type, and in the case of women who gave birth less than three times.

Keywords: stress urinary incontinence; perimenopausal period; physiotherapy; pelvic floor muscles; ICIQ LUTS qol; quality of life.

ICIQ LUTS qol badający QOL przed i po leczeniu zachowawczym. Dodatkowo zalecono estrogeny dopochwowe (estriol) przez cały okres leczenia. Do obliczeń statystycznych użyto pakiet Satistica v. 12.0 PL firmy StatSoft, USA.

Wyniki: Analiza wyników pochodzących z kwestionariusza ICIQ LUTS qol wykazała, iż jakość życia pacjentek poprawiła się w większości badanych obszarów. Istotna zmiana nie pojawiła się w relacjach międzyludzkich. Dowiedziono, iż w badanych grupach gimnastka MDM z mięśniem synergistycznym oraz gimnastyka wyizolowanych MDM jest skuteczna. Wykazano wpływ takich czynników jak WHR, liczba porodów czy status menopauzalny na skuteczność przeprowadzonego leczenia. Wnioski: Gimnastyka MDM i mięśnia synergistycznego oraz wyizolowanych MDM wpłynęły na poprawę QOL pacjentek z WNM I stopnia. Tylko status menopauzalny, WHR oraz liczba porodów wpłynęły na wynik leczenia zachowawczego.

Słowa kluczowe: wysiłkowe nietrzymanie moczu; perimenopauza; fizjoterapia; mięśnie dna miednicy; ICIQ LUTS qol; jakość życia.

* Zwięzła wersja rozprawy doktorskiej przyjętej przez Radę Wydziału Nauk o Zdrowiu Pomorskiego Uniwersytetu Medycznego w Szczecinie. Promotor: dr hab.n. med., prof. PUM Agnieszka Brodowska. Oryginał obejmuje: 132 strony, 15 tabel, 11 rycin i 213 pozycji piśmiennictwa. 


\section{WSTĘP}

Według International Continence Society (ICS) nietrzymanie moczu definiowane jest jako niekontrolowany wyciek moczu $[1,2]$. Światowa Organizacją Zdrowia wskazuje, iż jest to choroba społeczna, ponieważ z jej powodu cierpi ponad $5 \%$ populacji. W zależności od przyjętych kryteriów badania ocenia się, że dotyczy 30-60\% kobiet będących w okresie perimenopauzalnym. Największą częstość występowania objawów rejestruje się właśnie w piątej dekadzie życia.

Wysiłkowe nietrzymanie moczu (WNM) jest najczęściej występującą formą spośród pozostałych typów. Prawie 50\% kobiet deklarujących nietrzymanie moczu (NM) podaje objawy charakterystyczne dla tego rodzaju, tj.: wyciek moczu podczas kaszlnięcia, kichnięcia, śmiechu, podskoków, podnoszenia ciężkich przedmiotów [3]. Wspólnym elementem dla wymienionych aktywności jest pojawiający się wzrost ciśnienia śródbrzusznego (intra abdominal pressure - IAP), który wpływa na obciążenie dna miednicy. Inne rodzaje NM występują rzadziej. Szacuje się, iż ok. 32\% stanowią pacjentki z tzw. mieszanym NM. Jest to połączenie objawów WNM i NM naglącego. Rodzaj naglący jest rzadziej spotykany i dotyczy ok. 14\%. Jak sygnalizują międzynarodowe instytucje, nie ma pewności, jak często występuje NM, ponieważ jest to wstydliwy problem, o którym pacjentki nie chcą mówić [4]. Wszystkie rodzaje NM powodują znaczny spadek oceny jakości życia pacjentek. Liczne opracowania wskazują, jak szeroki jest wachlarz problemów emocjonalnych oraz trudności w funkcjonowaniu w społeczeństwie.

Obecnie przyjęty podział WNM na stopnie zaawansowania objawów wyróżnia: I stopień - występujący przy nagłym wzroście IAP (np. kaszel, kichanie, nagły wybuch śmiechu); II stopień - występujący przy łagodniejszym wzroście IAP (np. dźwiganie, bieganie); III stopień - gdy wypływanie moczu następuje przy niewielkim wzroście IAP, jak np. podczas wchodzenia lub schodzenia ze schodów, marszu, a nawet zmiany pozycji z leżącej na siedzącą. Badania DeLanceya jednoznacznie potwierdziły, iż efektywne utrzymywanie moczu jest związane z prawidłowym przenoszeniem ciśnienia w jamie brzusznej na bliższy odcinek cewki moczowej oraz połączenie pęcherzowo-cewkowe [5]. Zapobieganie wypływaniu moczu zależy również od prawidłowego aparatu podporowego, jakim jest zespół mięśni dna miednicy mniejszej [6].

Bump dzieli czynniki ryzyka NM u kobiet na: predysponujące, wywołujące, promujące i dekompensacyjne. Predysponujące mogą być czynniki: genetyczne, anatomiczne, rasowe, kulturowe, kolagenowe lub neurologiczne. Do czynników wywołujących zalicza się: uszkodzenia mięśni i/lub nerwów, porody naturalne, operacje chirurgiczne oraz czynniki popromienne. Czynniki promujące to: wiek kobiety, demencja, choroby środowiskowe. Do czynników dekompensacyjnych można zaliczyć: poziom aktywności fizycznej pacjentki, dysfunkcje jelit, zakażenia dolnych dróg moczowych, stosowaną przez pacjentkę dietę, czynniki polekowe, choroby psychiczne, otyłość i menopauzę [7]. Zwracając szczególną uwagę na rozpatrywane w niniejszej pracy czynniki ryzyka, należy jeszcze wymienić: status menopauzalny pacjentek, wskaźnik masy ciała (body mass index - BMI), wskaźnik dystrybucji tkanki tłuszczowej w organizmie (waist-hip ratio - WHR) oraz liczbę naturalnych porodów.

Możliwości diagnostyczne dla WNM są szerokie. Do klasycznego postępowania zaliczyć należy szczegółowy wywiad, badanie urodynamiczne, Q-tip test, test podpaskowy, dzienniczek mikcji czy ultrasonografię miednicy mniejszej. W diagnostyce NM można również posłużyć się dodatkowo kwestionariuszem jakości życia (QOL), aby ocenić stopień zaawansowania oraz wpływu na funkcjonowanie w społeczeństwie pacjentki. Na szczególną uwagę zasługuje również diagnostyka fizjoterapeutyczna oparta na powierzchniowym badaniu elektromiograficznym, badaniu stanu funkcjonalnego mięśni dna miednicy (MDM) z wykorzystaniem schematu PERFECT w skali Oksfordzkiej czy z użyciem perineometru.

Wdrożenie leczenia WNM zależy od stopnia zaawansowania objawów. IUGA, ICS, PTUG, PTG, EAU zwracają szczególną uwagę na fakt, iż powinno rozpocząć się od leczenia zachowawczego, a następnie stosować inne metody, jeśli te pierwsze nie przyniosły oczekiwanych rezultatów. Do metod leczenia zachowawczego można zaliczyć w pierwszej kolejności ćwiczenia MDM mniejszej, które szeroko opisywane są w literaturze tematu i określane przez EAU jako zalecane. Siła zalecenia określana jest na poziomie A, co oznacza, że powstały one na podstawie badań z randomizacją lub wartościowych badań klinicznych. Do tego poziomu zaliczana jest również zmiana trybu życia pacjentki, a szczególnie obniżenie masy ciała. Inną metodą leczniczą jest elektrostymulacja, która jednak rekomendowana jest tylko na poziomie C. Nie ma wiarygodnych badań potwierdzających tę metodę, brakuje usystematyzowanych parametrów stosowanego prądu, a dodatkowym argumentem, który zgłaszają pacjentki, jest dyskomfort powstający w wyniku działania prądu na tkanki pochwy.

Ćwiczenia MDM znane są od ponad 6000 lat. Swoją potoczną nazwę mięśnie Kegla uzyskały od twórcy pierwszej naukowej metody badania i ćwiczenia za pomocą perineometru dra Arnolda Kegla. Celem ćwiczeń tej grupy mięśni jest zbudowanie warstwy, która wytwarza dobre mechaniczne podparcie i wpływa na wzrost ciśnienia w cewce moczowej, co potwierdzili w badaniach DeLancey [5], Bø i wsp. [8] czy Tomson i O’Sullivan [9]. Dowiedziono, że ćwiczenia indywidualne są bardziej efektywne niż grupowe. Gimnastyka powinna być celowana na MDM z wyeliminowaniem błędów, które wg Bø i wsp. dotyczą napinania innych grup mięśniowych zamiast MDM, nieprawidłowego oddechu i wykonywania parcia zamiast napięcia. Badania Sapsford [10] wykazały, że ta grupa mięśniowa nie pracuje samodzielnie. Do mięśni synergistycznych zalicza się mięśnie brzucha, mięsień pośladkowy wielki (musculus gluteus major) oraz mięśnie przywodziciele ud (musculus adductor femoris). Działanie mięśni brzucha w połączeniu z MDM dotyczy najmocniej mięśnia poprzecznego brzucha (musculus transversus abdominis - TrA), co zostało zaobserwowane w badaniach Pereira i wsp. [11]. Potwierdzono wówczas, że następuje aktywacja TrA w momencie napięcia MDM oraz brak aktywacji u kobiet 
będących po porodzie naturalnym. Mięsień TrA jest najwyraźniejszym synergistą dla MDM.

Pozostałe metody leczenia WNM związane są z zabiegami operacyjnymi w postaci taśm polipropylenowych zakładanych w celu podparcia w części środkowej i tylnej cewki moczowej [12]. Zabiegi te jednak powinny być stosowane po leczeniu zachowawczym dla II i III stopnia WNM. Leczenie farmakologiczne w przypadku tego typu NM polega głównie na stosowaniu estrogenoterapii dopochwowej, której celem jest stymulacja wzrostu nabłonka pochwy i przepływu krwi w jej ścianach, poprawa nawilżenia oraz odporności na infekcje. W układzie moczowym estrogenoterapia wpływa na zwiększenie liczby receptorów $\alpha$-adrenergicznych, poprawę transmisji ciśnienia w proksymalnej części cewki i wzrost ciśnienia jej zamknięcia.

Celem pracy badawczej było porównanie jakości życia pacjentek z WNM I stopnia po zastosowaniu gimnastyki mięśni dna miednicy z mięśniem synergistycznym oraz gimnastyki wyłącznie wyizolowanymi mięśniami dna miednicy przez okres 3 miesięcy. Ponadto ocena wpływu menopauzy, masy ciała wyrażonej poprzez BMI, dystrybucji tkanki tłuszczowej wg WHR oraz liczby porodów na skuteczność gimnastyki mięśni dna miednicy z mięśniem synergistycznym oraz gimnastyki wyłącznie wyizolowanymi mięśniami dna miednicy.

\section{MATERIA $Y$ I METODY}

Do badania zakwalifikowano 140 pacjentek, u których w Klinice Ginekologii, Endokrynologii i Onkologii Ginekologicznej Pomorskiego Uniwersytetu Medycznego w Szczecinie - PUM (dawniej Klinika Ginekologii i Uroginekologii PUM) zostało zdiagnozowane za pomocą badania urodynamicznego oraz kwestionariusza Gaudenza WNM I stopnia. Na wykonanie badań uzyskano zgodę Komisji Bioetycznej PUM. Pacjentki spełniały kryteria włączenia, do których zaliczono: wiek 45-6o lat, zdiagnozowane WNM I stopnia oraz zgodę na udział w badaniach. Za kryteria wyłączenia uznano: wiek poniżej 45 i powyżej 60 lat, inny stopień WNM, inny rodzaj NM, towarzyszące obniżenie narządów miednicy mniejszej, infekcje dolnych dróg moczowych oraz brak pisemnej zgody na badania.
Pacjentki zostały podzielone na 2 grupy o równej liczebności: grupę A oraz grupę B. Wykonane zostały kwestionariusze autorski oraz ICIQ LUTS qol, a następnie zlecony schemat gimnastyczny A dla grupy A, schemat gimnastyczny B dla grupy B i estrogenoterapia dopochwowa przez okres 3 miesięcy dla obu grup. Po 3 miesiącach wykonany został ponownie kwestionariusz ICIQ LUTS qol. W obu grupach zastosowane zostały estrogeny dopochwowe w postaci globulek z estriolem (0,5 mg).

Schemat gimnastyczny dla grupy A przebiegał w następującej kolejności: napięcie MDM z napięciem TrA, z kontrolą wydechu w pozycji leżenia tyłem. Pacjentki ćwiczyły 4 razy w tygodniu, powtarzając 3 serie po 10 powtórzeń tzw. długich napięć (6-8 s) o sile 60-70 MVC (maximal voluntary contraction; maksymalnej dowolnej siły skurczu) oraz 2 serie po 10 powtórzeń tzw. krótkich napięc (1-2 s) o sile 30-60\% MVC. Pacjentki były również zobligowane do zastosowania tzw. Knack Maneuvre. Szybkiego skurczu MDM poprzedzającego kichnięcie, kaszlnięcie, dźwignięcie, które generują wzrost IAP. Schemat gimnastyczny B dla grupy B przebiegał analogicznie, z pominięciem napięcia mięśnia TrA. W schemacie B napinane były jedynie MDM. Tak więc schemat A to ćwiczenia mięśni dna miednicy i mięśnia synergistycznego (MS), a schemat B to ćwiczenia tylko mięśni dna miednicy.

Zastosowane metody statystyczne obejmowały badanie rzetelności testu wykonane za pomocą Alfa Cronbacha, normalności rozkładów zmiennych ciągłych - metodą ShapiroWilka, porównanie grup testem t-Studenta i testem $\chi^{2}$ Pearsona. Zmienne uzyskane z ankiet analizowano poprzez 2-czynnikową i 3-czynnikową ANOVA oraz test post hoc Tukeya. Za istotność statystyczną przyjęto poziom $\mathrm{p}<0,05$ (tab. 1).

\section{WYNIKI}

W tabeli 2 przedstawiono porównanie wyników przeprowadzonego wg 2 schematów (A i B) leczenia zachowawczego. W kwestionariuszu zastosowano pytania dotyczące wielu aspektów emocjonalnych składających się na jakość życia. Każdemu z obszarów nadano symbol od Q3 do Q8 oraz QW (pojawiający się wstyd związany z popuszczaniem moczu) i suma scores (sumaryczna punktacja z całego kwestionariusza).

TABELA 1. Ogólna charakterystyka badanych grup A i B

\begin{tabular}{|c|c|c|c|c|}
\hline \multicolumn{2}{|c|}{ Parametry } & Grupa A & Grupa B & $p$ \\
\hline \multicolumn{2}{|l|}{ Wiek $(\bar{x}+S D$, lata $)$} & $53,1 \pm 5,5$ & $53,0 \pm 5,7$ & $0,813^{*}$ \\
\hline \multicolumn{2}{|l|}{$\mathrm{BMI}\left(\overline{\mathrm{x}}+\mathrm{SD}, \mathrm{kg} / \mathrm{m}^{2}\right)$} & $27,4 \pm 4,6$ & $27,4 \pm 5,0$ & $1,0^{*}$ \\
\hline \multirow{2}{*}{ Miejsce zamieszkania (\%) } & miasto & 75,7 & 77,1 & \multirow{2}{*}{0,842} \\
\hline & wieś & 24,3 & 22,9 & \\
\hline \multirow[t]{2}{*}{ Tryb życia (\%) } & aktywny & 30,0 & 25,7 & \multirow[t]{2}{*}{0,616} \\
\hline & mieszany & 57,1 & 55,7 & \\
\hline \multirow{2}{*}{ Status menopauzalny (\%) } & przedmenopauzalny & 47,1 & 61,4 & \multirow{2}{*}{0,09} \\
\hline & pomenopauzalny & 52,9 & 38,6 & \\
\hline
\end{tabular}

p- $\chi^{2}$ Pearsona; $\bar{x}$-średnia; SD - odchylenie standardowe; BMI - wskaźnik masy ciała; WHR - wskaźnik dystrybucji tkanki tłuszczowej w organizmie; * test t-Studenta 
TABELA 2. Porównanie wyników po przeprowadzeniu leczenia zachowawczego WNM I stopnia w grupie A i B

\begin{tabular}{|c|c|c|c|c|c|}
\hline \multirow{2}{*}{ Scores } & \multicolumn{2}{|c|}{ Grupa A } & \multicolumn{2}{|c|}{ Grupa B } & \multirow{2}{*}{$\mathrm{p}$} \\
\hline & $\bar{x}$ & $\pm S D$ & $\bar{x}$ & $\pm S D$ & \\
\hline $\begin{array}{l}\text { Ograniczenia } \\
\text { wykonywania obowiązków } \\
\text { domowych (Q3) }\end{array}$ & 18,1 & 20,0 & 30,5 & 20,1 & $<0,0001$ \\
\hline Ograniczenia fizyczne (Q4a) & 19,5 & 15,0 & 33,6 & 21,3 & $<0,0001$ \\
\hline Ograniczenia socjalne (Q4b) & 6,8 & 9,7 & 22,1 & 16,7 & $<0,0001$ \\
\hline $\begin{array}{l}\text { Ograniczenia relacji (Q5) } \\
\text { międzyludzkich }\end{array}$ & 15,0 & 24,9 & 26,4 & 26,5 & 0,132 \\
\hline Emocje (Q6) & 11,4 & 14,2 & 27,9 & 20,7 & $<0,0001$ \\
\hline Ospałość/energia (Q7) & 19,8 & 19,9 & 34,3 & 19,0 & $<0,0001$ \\
\hline $\begin{array}{l}\text { Zmiany podkładek, } \\
\text { zmniejszenie ilości } \\
\text { wypijanych napojów, zmiana } \\
\text { bielizny po zmoczeniu (Q8) }\end{array}$ & 24,3 & 17,9 & 43,0 & 17,3 & $<0,0001$ \\
\hline Wstyd (QW) & 14,8 & 21,0 & 31,4 & 26,6 & 0,011 \\
\hline Suma scores & 129,7 & 98,3 & 249,2 & 104,3 & $<0,0001$ \\
\hline
\end{tabular}

Scores - punktacja dla zespołu pytań; $\bar{x}$ - średnia; SD - odchylenie standardowe; $\mathrm{p}$ - test t-Studenta

Ocena QOL pacjentek po leczeniu zachowawczym WNM I stopnia wśród osób z grupy A i B wskazywała istotną poprawę w większości obszarów. Nie nastąpiła istotna zmiana w obszarze relacji międzyludzkich. Gimnastyka wg schematu A (MDM i MS) była bardziej skuteczna od gimnastyki wg schematu B (MDM).

Po wykonaniu analizy statystycznej z użyciem 2-czynnikowej ANOVA w większości badanych obszarów jakości życia pacjentek z WNM I stopnia wykazano istotną skuteczność zastosowanych ćwiczeń zarówno wg schematu A (MDM i MS), jak i wg schematu B (MDM). Większą skuteczność wykazał schemat gimnastyczny A. Najmniej zmieniającym się pod wpływem gimnastyki obszarem były relacje międzyludzkie (Q5) - tabela 3.

Wykazano istotną statystycznie różnicę pomiędzy grupami A i B w zakresie WHR. Pozostałe różnice nie były znaczące. Wykonano 3-czynnikową analizę wariancji, w której oceniono wpływ czynników modyfikujących skuteczność przeprowadzonego leczenia zachowawczego na jakość życia pacjentek. W wyniku tej analizy zaobserwowano na podstawie kwestionariusza ICIQ LUTS qol, iż status menopauzalny badanych pacjentek ma wpływ na uzyskane wyniki. Można przyjąć, że pacjentki będące w okresie przedmenopauzalnym osiągały lepsze wyniki w badaniach, tj. poprawiała się ich ocena jakości życia. Również WHR wpływał na skuteczność gimnastyki wg schematu A i B. Pacjentki, których typ budowy ciała określany był jako gynoidalny (WHR $<0,8$ ), gdzie koncentracja tkanki łącznej dotyczyła głównie bioder, pośladków i ud, miały lepsze wyniki w większości obszarów QOL. Pacjentki, które rodziły naturalnie mniej niż 3 razy, również wykazały lepszą skuteczność zastosowanego leczenia zachowawczego. Wskaźnik masy ciała jako jedyny nie wpłynął istotnie statystycznie na wyniki badań skuteczności gimnastyki wg schematu A i B (tab. 4).

\section{DYSKUSJA}

Jakość życia kobiet z wysiłkowym nietrzymaniem moczu I stopnia można ocenić poprzez kwestionariusz ICIQ LUTS qol, którym szczegółowo analizuje się poszczególne jej aspekty. Zastosowane narzędzie badawcze pozwoliło na przeprowadzenie dowodu skuteczności gimnastyki mięśni dna miednicy i mięśnia synergistycznego oraz wyizolowanych mięśni dna miednicy.

Wpływ WNM na wykonywanie prac domowych (sprzątanie, robienie zakupów) czy pracę zawodową i inne czynności poza domem (Q3) w badaniach własnych istotnie się zmniejszył. Do podobnych wyników doszli Fitz i wsp. [13], którzy wykonali badania wśród 36 kobiet w wieku 55,2 \pm 9 poddanych treningowi MDM. Należy podkreślić, iż zastosowana gimnastyka dotyczyła jedynie wyizolowanych MDM. Podobnie u Rett i wsp. [14] poprawa nastąpiła już po 6 tygodniach leczenia. Można wnioskować, iż na takie rezultaty wpłynęła zastosowana tutaj metoda biofeedback. Aktywność fizyczna i podróżowanie (Q4a) jest obszarem QOL zawartym w kwestionariuszu ICIQ LUTS qol, który w badaniach własnych wykazał istotną poprawę. Jest to wynik potwierdzający doświadczenia innych badaczy. Hirakawa i wsp. [15] analizowali skuteczność ćwiczeń MDM i ćwiczeń MDM z metodą biofeedbak, które zalecono pacjentkom przez 12 tygodni. Wpływ tych metod na QOL, a szczególnie na aktywność fizyczną, wykazali również Capellini i wsp. [16].

Obszar QOL, który określany jest w kwestionariuszu jako Q4b i dotyczy odwiedzania, spotykania się z przyjaciółmi, a także życia rodzinnego, w badaniach własnych również został oceniony przez pacjentki jako istotnie poprawiający się po zastosowanej gimnastyce. Analizując literaturę, można dostrzec w badaniach Fitz i wsp. [13] podobne rezultaty. Leczenie przeprowadzone przez ten zespół trwało 12 tygodni i obejmowało 10 wolnych skurczy oraz 3-4 szybkie wykonywane w pozycji leżenia tyłem, w siadzie oraz w staniu. Do innych rezultatów doszli Nascimento-Correia i wsp. [17], pomimo że trening MDM trwał tyle samo.

Pytania dotyczące relacji z partnerem i życia płciowego pacjentek (Q5) w ogólnej analizie własnych wyników wykazywały, iż obszar ten nie uległ znaczącej zmianie. Do podobnych wyników doszli Fitz i wsp. [13], których program usprawniania obejmował 3 miesiące ćwiczeń wyizolowanych MDM z wykwalifikowanym fizjoterapeutą uroginekologicznym. Także badania Rett i wsp. [14] potwierdziły brak istotnej zmiany w tym obszarze. Ponieważ dobrze funkcjonujące dno miednicy jest związane z większą aktywnością seksualną, można wnioskować, że pacjentki potrzebują więcej czasu na dokonanie zmian emocjonalnych [18], aby móc lepiej oceniać ten obszar. Pacjentki z NM 3 razy częściej zapadają na depresję niż kobiety niemające problemów z dolnymi drogami moczowymi, dlatego obszar emocji związanych z WNM został dokładnie zbadany. Pojawianie się przygnębienia, zaniepokojenia, nerwowości czy złego zdania o sobie w badaniach własnych zmniejszyło się istotnie statystycznie po przeprowadzeniu leczenia zachowawczego wg obu schematów. Podobne wyniki uzyskali Balmforth 
TABELA 3. Dwuczynnikowa ANOVA w układzie grupa A i B, przed i po leczeniu zachowawczym

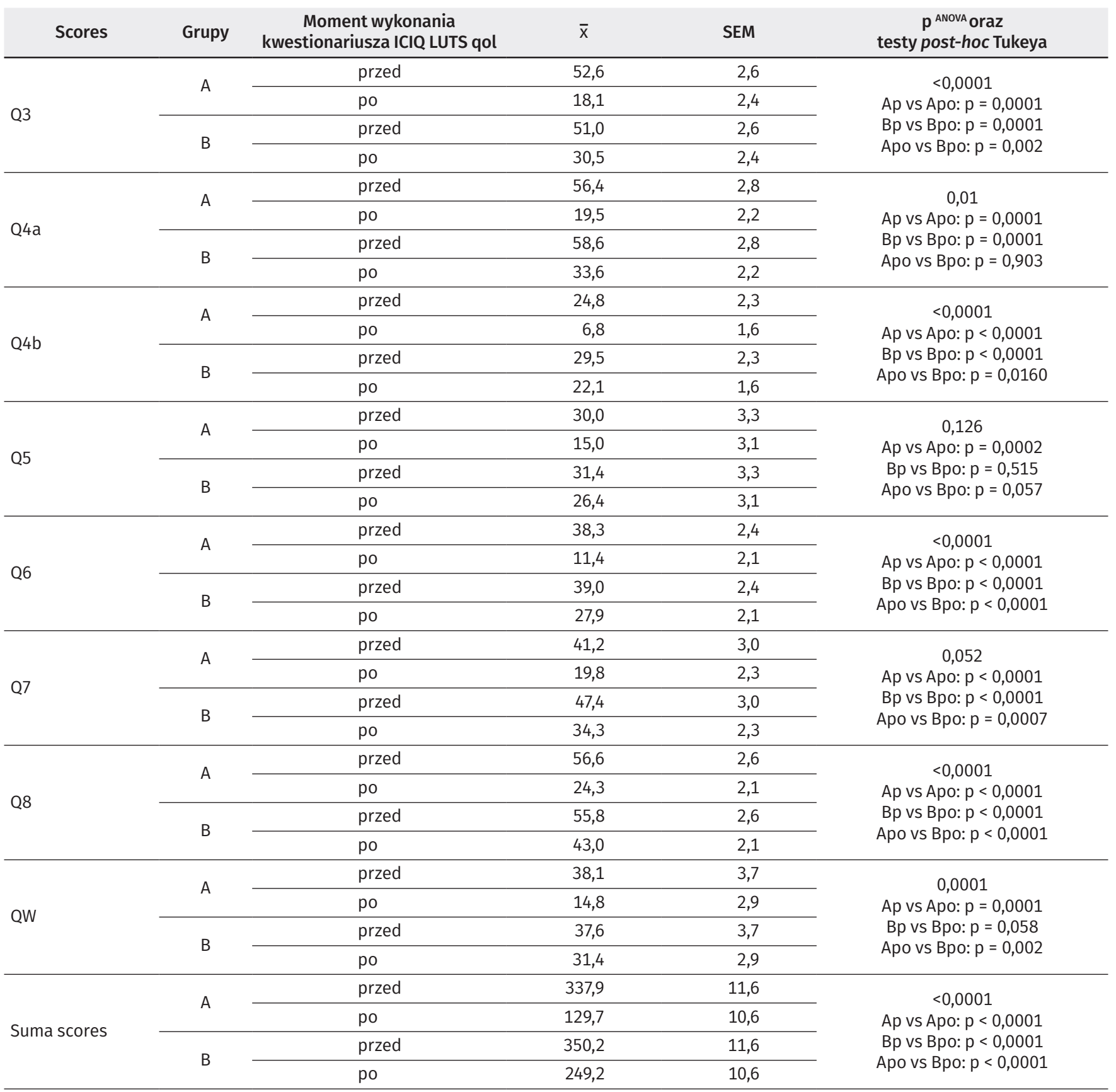

Scores - punktacja dla zespołu pytań; $\bar{x}$ - średnia; SEM - błąd standardowy; Ap - poziom uzyskanych punktów w grupie A przed leczeniem zachowawczym; Apo poziom uzyskanych punktów w grupie A po leczeniu zachowawczym; Bp - poziom uzyskanych punktów w grupie B przed leczeniem zachowawczym; Bpo - poziom uzyskanych punktów w grupie B po leczeniu zachowawczym

TABELA 4. Porównanie częstości występowania w grupie A i B czynników modyfikujących (w \%)

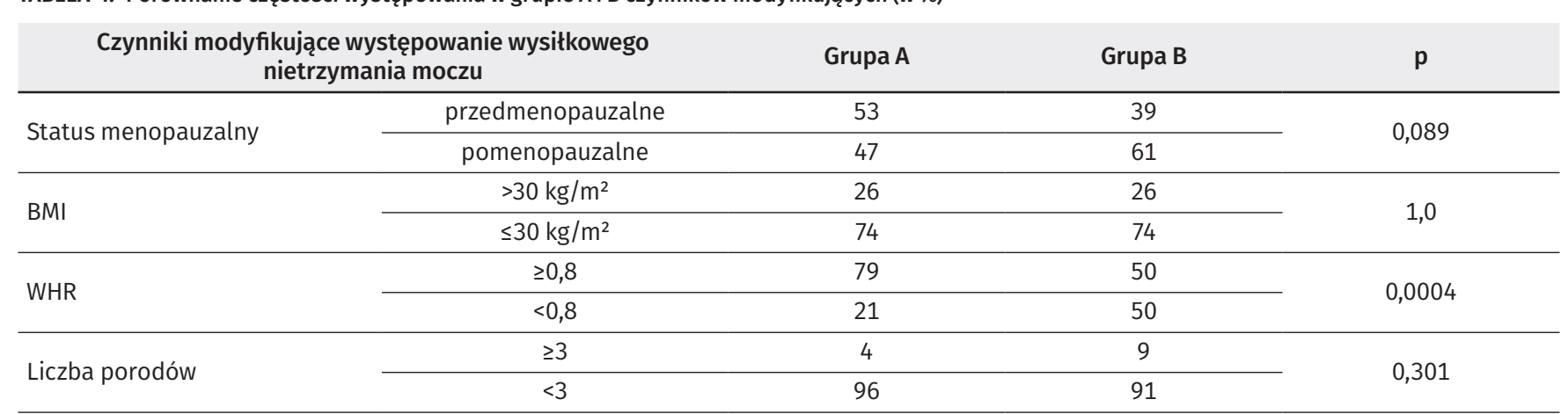

p - X² Pearsona; BMI - wskaźnik masy ciała; WHR - wskaźnik dystrybucji tkanki tłuszczowej w organizmie 
i wsp. [19]. Pacjentki poddawane były treningowi wyłącznie MDM przez 14 tygodni. Wysiłkowemu nietrzymaniu moczu może towarzyszyć wyczerpanie lub zmęczenie (Q7). W wynikach własnych ten obszar uległ znaczącej poprawie. Pacjentki nie zgłaszały już takich objawów i deklarowały możliwość odprężenia z powodu zmniejszających się dolegliwości. Także w badaniach Nascimento-Correia i wsp. [17] wskazano istotną różnicę, pomimo iż sesja ćwiczeniowa trwała 1 godz. i realizowana była tylko 1 raz w tygodniu. Być może przeprowadzone przez Pereira i wsp. [11] badania trwały zbyt krótko, ćwiczenia MDM zalecane były przez 6 tygodni, 2 razy dziennie, po 1 godz., ponieważ nie przyniosły takich rezultatów. Pacjentki nie wskazały istotnych zmian w pojawianiu się wyczerpania, zmęczenia czy kłopotów ze snem, pomimo iż faktyczna ilość sesji gimnastycznych była analogiczna jak w badaniach opisanych w niniejszej pracy.

Obszar Q8 obejmował pytania dotyczące noszenia podkładek higienicznych, kontroli spożywania płynów, zmiany bielizny po zmoczeniu czy martwienia się z powodu nieprzyjemnego zapachu. Badania własne potwierdziły, iż pacjentki faktycznie rzadziej mają potrzebę zmiany podkładek czy zmoczonej bielizny i nie kontrolują już ilości spożywanych płynów. Capellini i wsp. [16], którzy badali 14 pacjentek, zalecając ćwiczenia MDM z metodą biofeedback przez 12 tygodni, również doszli do podobnych spostrzeżeń. Leczenie zachowawcze WNM, które przeprowadzono przez zespół Rett i wsp. [14], pomimo iż trwało tylko 6 tygodni, przyniosło równie pozytywne rezultaty.

Ważnym emocjonalnym problemem, z jakim borykają się pacjentki z WNM, jest wstyd. Biorąc pod uwagę takie problemy zdrowotne jak depresja czy nowotwór, to właśnie NM jest oceniane jako najbardziej wstydliwe. W badaniach własnych potwierdzono, że ten badany obszar (QW) uległ zmianie; została wykazana istotna statystycznie różnica po przeprowadzonym leczeniu zachowawczego. Wan i wsp. [20] badali 333 chińskich kobiet i stwierdzili, że QOL obniżała się wraz z nasileniem objawów WNM, wzrastała społeczna izolacja i poczucie wstydu. Można wnioskować, iż w badaniach własnych wystąpił odwrotny mechanizm i wraz z poprawą wydolności MDM oraz zmniejszenia objawów NM zmalało poczucie wstydu.

Ogólne poczucie QOL, jakie można zaobserwować w wynikach suma scores, nie jest najlepszym narzędziem do jego oceny, ponieważ kwestionariusz ICIQ LUTS qol jest niezwykle rozbudowany i szczegółowy. Globalne poczucie QOL może jednak posłużyć do porównania wyników z innymi badaczami. W pracy własnej ocena tego obszaru wykazała, iż oba schematy gimnastyczne były skuteczne. W badaniach Farzinmehr i wsp. [21] porównano trening wibracyjny oraz klasyczny trening gimnastyczny MDM, używając do oceny jakości życia pacjentek kwestionariusza I-QOL (incotinence- quality of life). Wykazano, iż stosowanie przez 12 tygodni gimnastyki MDM w różnych pozycjach ciała, z powtórzeniem 3-4-krotnie serii i przerwą $60 \mathrm{~s}$ pomiędzy seriami, jest skutecznym sposobem złagodzenia objawów WNM u kobiet.

Wpływ takich czynników jak status menopauzalny pacjentki, masa ciała, a szczególnie otyłość, WHR opisujący dystrybucję tkanki tłuszczowej w organizmie oraz liczba porodów, został zbadany przy użyciu analizy wariancji. Obniżenie stężenia estrogenów prowadzi do rozległych zmian atroficznych, również w obszarze dna miednicy. Zarówno gimnastyka MDM, jak i stosowana przez okres 3 miesięcy estrogenoterapia dopochwowa (estriol) miały wpłynąć na poprawę ukrwienia i unerwienia okolicy miednicy mniejszej, zbudować masę mięśniową i wytworzyć tym samym dobre podparcie dla cewki moczowej. W badaniach własnych większość ocenianych obszarów QOL wykazała poprawę u kobiet będących w okresie premenopauzalnym. Inne wyniki uzyskali Nygaard i wsp. [22] wśród 47 przed- i 35 pomenopauzalnych kobiet ćwiczących MDM wg treningu opracowanego przez Physiotherapy Departament of London Hospital University. Na efekty przeprowadzonego leczenia zachowawczego w postaci gimnastyki trwającej 20 miesięcy oraz doustnej hormonalnej terapii zastępczej nie wpłynął status menopauzalny pacjentek.

Otyłość (>30 kg/m²) BMI jest czynnikiem stosunkowo często wymienianym jako jedna z przyczyn WNM. Wzmożone ciśnienie śródbrzuszne, które występuje pod wpływem tkanki tłuszczowej zgromadzonej w jamie brzusznej, może być przyczyną wzrostu ciśnienia w pęcherzu moczowym oraz nadmiernej ruchomości cewki moczowej. W badaniach własnych dowiedziono, że sam BMI nie wpłynął na efektywność zastosowanego leczenia zachowawczego. Zarówno kobiety o wyższym, jak i niższym BMI w badanych obszarach wykazywały efektywność gimnastyki dwoma metodami, tj. wg schematu A i B. Analizując literaturę, w której do badania QOL uży to kwestionariusza KHQ (Kings Health Questionnaire), stwierdzono, iż w odniesieniu do WNM obserwowano głównie kobiety o niższym wskaźniku, np. u Hirakawa i wsp. [15] wynosił on $22,5 \mathrm{~kg} / \mathrm{m}^{2}$ i $23,9 \mathrm{~kg} / \mathrm{m}^{2}$ w porównywanych grupach czy u Nascimento-Correia i wsp. [17] 26,03 kg/m² i 26,0 kg/m². Wobec powyższego porównywanie wyników badań nie będzie właściwe w tym przypadku.

Do czynników wpływających na efektywność leczenia zaliczono również WHR. Uznano, iż rozłożenie tkanki tłuszczowej w organizmie może mieć znaczenie dla obciążenia dna miednicy. W analizie własnych wyników wykazano, że gynoidalny typ budowy ciała, gdzie tkanka tłuszczowa gromadzi się poniżej dna miednicy (WHR < 0,8), osiąga lepsze rezultaty w ćwiczeniach MDM oraz lepiej ocenia swoją QOL. W badaniach Kamel i wsp. [23] oceniano wpływ masy ciała otyłych kobiet (WHR $\geq 0,8$ oraz $>30 \mathrm{~kg} / \mathrm{m}^{2}$ ) na efekt ćwiczeń MDM. Pacjentki podzielone na 2 grupy przez 12 tygodni, w sesjach odbywających się 3 razy w tygodniu, wykonywały ćwiczenia - mięśni brzucha (grupa 1) i MDM (grupa 2). Ocenę leczenia przeprowadzono po 12 i 24 tygodniach. Wykazano, że androidalny typ budowy ciała nie stanowi przeszkody do uzyskania istotnych efektów. Wniosek ten jest odmienny od prezentowanego w niniejszej pracy. Należy podkreślić, iż badacze potwierdzili zmniejszenie WHR pod wpływem gimnastyki.

W prezentowanej pracy na podstawie licznych doniesień założono, że liczba naturalnych porodów $\geq 3$ wpływa na niewydolność dna miednicy mniejszej. W wyniku analizy dowiedziono, iż kobiety rodzące mniej niż 3 razy osiągały lepsze 
rezultaty. Hirakawa i wsp. [15] porównywali efekty ćwiczeń MDM klasycznych oraz ćwiczeń MDM z metodą biofeedback wśród 46 pacjentek z WNM. Kobiety zgłaszały poprawę w większości badanych obszarów jakości życia. Ilość porodów była deklarowana na poziomie $2,1 \pm 0,6 \mathrm{w}$ badanych grupach. Wynik ten jest analogiczny do prezentowanego w niniejszej pracy.

\section{WNIOSKI}

1. Gimnastyka mięśni dna miednicy i mięśnia synergistycznego (mięśnia poprzecznego brzucha) oraz gimnastyka wyizolowanych mięśni dna miednicy wpływa na poprawę jakości życia kobiet z wysiłkowym nietrzymaniem moczu, jednak bardziej skuteczna jest fizjoterapia mięśni dna miednicy i mięśnia synergistycznego (mięśnia poprzecznego brzucha).

2. Gimnastyka MDM jest bardziej skuteczna u kobiet w okresie przedmenopauzalnym, o typie budowy ciała gynoidalnym oraz rodzących naturalnie mniej niż 3 razy.

3. Wskaźnik masy ciała nie wpłynął na wyniki skuteczności gimnastyki u pacjentek z wysiłkowym nietrzymaniem moczu.

\section{PIŚMIENNICTWO}

1. Abrams P, Andersson KE, Birder L, Brubaker L, Cardozo L, Chapple C, et al. $4^{\text {th }}$ International Consultation on Incontinence Recommendations of the International Scientific Committee: Evaluation and Treatment of Urinary Incontinence, Pelvic Organ Prolapse and Fecal Incontinence. 2009. http://www.ics.org/publications/ici_4/files-book/recommendation.pdf (7.01.2016).

2. Haylen BT, Ridder D, Freeman RM, Steven E, Swift SE, Berghmans B, et al. International Urogynecological Association; International Continence Society. An International Urogynecological Association (IUGA)/International Continence Society (ICS) Joint Report on the Terminology for Female Pelvic Floor Dysfunction. Neurourol Urodyn 2010;29:4-20.

3. Brodowska A. Ginekologia od teorii do praktyki. In: Brodowska A, editor. Menopauza. Szczecin: Wydawnictwo Pomorskiego Uniwerytetu Medycznego w Szczecinie; 2014. p. 179-93.

4. Resnick NM. Urinary incontinence. Lancet 1995;6:94-9.

5. DeLancey JOL. Structural support of the urethra as it relates to stress urinary incontinence: the hammock hypothesis. Am J Obstet Gynecol 1994;170:1713-23.

6. Petros PE, Ulmsten U. An integral theory of female urinary incontnece. Acta Obstet Gynecol Scand 1990;153(69):1-79.

7. Bump RC. Discussion: Epidemiology of urinary incontinence. Urology 1997;50:15-6.
8. Bø K, Lilleas F, Talseth T, Hedland H. Dynamic MRI of the pelvic floor muscles in an upright sitting position. Neurourol Urodyn 2001;20(2):167-74.

9. Thompson JA, O'Sullivan PB. Levator plate movement during voluntary pelvic floor muscle contraction in subjects with incontinence and prolapse: a cross-sectional study and review. Int Urogynecol J Pelvic Floor Dysfunct 2003;14(2):84-8.

10. Sapsford R. Rehabilitation of pelvic floor muscles utilizing trunk stabilization. Manual Therapy 2004;9:3-12.

11. Pereira LC, Botelho S, Marques J, Amorim CF, Lanza AH, Palma P, et al. Are transversus abdominis/oblique internal and pelvic floor muscles coactivated during pregnancy and postpartum? Neurourol Urodyn 2013;32(5):416-9.

12. Ciećwież S, Nawrocka-Rutkowska J, Ciećwież M, Brodowska A, Starczewski A, Kotlęga D, et al. Porównanie skuteczności operacyjnego leczenia wysiłkowego nietrzymania moczu metodami slingowymi oraz sposobem Burcha z wykorzystaniem kwestionariusza Gaudenza. Perinatol Neonatol Ginekol 2011;4(4):185-91.

13. Fitz FF, Costa TF, Yamamoto DM, Resende APM, Stüpp L, Sartori MGF, et al. Impact of pelvic floor muscle training on the quality of life in women with urinary incontinence. Rev Assoc Med Bras 2012;58(2):155-9.

14. Rett MT, Simőes JA, Herrmann V, Gurgel MSC, Morais SS. Qualidade de vida em mulheres após tratamento da incontinência urinária de esforço com fisioterapia. Rev Bras Ginecol Obstet 2007;29:134-40.

15. Hirakawa T, Suzuki S, Kato K, Gotoh M, Yoshikawa Y. Randomized controlled trial of pelvic floor muscle training with or without biofeedback for urinary incontinence. Int Urogynecol J 2013;24(8):1347-54. doi: 10.1007/ s00192-012-2012-8.

16. Capellini MV, Riccetto CL, Dambros M, Tamanini JT, Herrmann V, Muller V. Pelvic floor exercises with biofeedback for stress urinary incontinence. Int Braz J Urol 2006;32(4):462-9.

17. Nascimento-Correia G, Santos-Pereira V, Tahara N, Driusso P. Effects of pelvic floor muscle training on quality of life of a group of women with urinary incontinence: randomized controlled trial. Actas Urol Esp 2012;36(4):216-21

18. Kanter G, Rogers RG, Pauls RN, Kammerer-Doak D, Thakar R. A strong pelvic floor is associated with higher rates of sexual activity in women with pelvic floor disorders. Int Urogynecol J 2015;26(7): 991-6.

19. Balmforth JR, Mantle J, Bidmead J, Cardozo L. A prospective observational trial of pelvic floor muscle training for female stress urinary incontinence. BJU Int 2006;98(4):811-7.

20. Wan X, Wang C, Xu D, Guan X, Sun T, Wang K. Disease stigma and its mediating effect on the relationship between symptom severity and quality of life among community-dwelling women with stress urinary incontinence: a study from a Chinese city. J Clin Nurs 2014;23(15-16):2170-9.

21. Farzinmehr A, Moezy A, Koohpayehzadeh J, Kashanian M. A comparative study of whole body vibration training and pelvic floor muscle training on women's stress urinary incontinence: three-month follow-up. J Family Reprod Health 2015;9(4):147-54.

22. Nygaard CC, Betschart C, Hafez AA, Lewkis E, Chasiotis I, Doumouchtsis SK. Impact of menopausal status on the outcome of pelvic floor physiotherapy in women with urinary incontinence. Int Urogynecol J 2013;24:2071-6.

23. Kamel DM, Thabet AA, Tantawy SA, Radwan MM. Abdominal versus pelvic floor muscles exercises in mild stress urinary incontinence in obese Egyptian women. Indian J Physiotherapy Occupational Therapy 2012;6(2):36-40. 